\title{
Metal Oxide Thin Films Grafted on Silica Gel Surfaces: Recent Advances on the Analytical Application of these Materials
}

\author{
Yoshitaka Gushikem* and Simone S. Rosatto
}

Instituto de Química, UNICAMP, CP 6154, 13083-970 Campinas - SP, Brazil

\begin{abstract}
Nos óxidos metálicos $\mathrm{M}_{\mathrm{x}} \mathrm{O}_{\mathrm{y}}$ altamente dispersos como monocamadas finas sobre a superfície porosa de $\mathrm{SiO}_{2}$ (denominados como $\mathrm{SiO}_{2} / \mathrm{M}_{\mathrm{x}} \mathrm{O}_{\mathrm{y}}$ ), a ligação covalente $\mathrm{Si}-\mathrm{O}-\mathrm{M}$ formada sobre a superfície $\mathrm{SiO}_{2}$ restringe a mobilidade dos óxidos ancorados resultando em óxidos metálicos coordenativamente insaturados (LAS) em adição aos sítios ácidos de Br申nsted (BAS). Os BAS originam-se dos grupos $\mathrm{MOH}$ e $\mathrm{SiOH}$, sendo o último devido aos grupos silanóis não reagidos. Como os óxidos ancorados estão fortemente imobilizados sobre a superficie, eles são também muito estáveis termicamente. O caráter anfotérico de muitos dos óxidos ancorados, permite a imobilização de várias espécies químicas, ácidos ou bases, resultando em uma ampla aplicação destes materiais com superfícies modificadas. Neste trabalho, muitas das recentes aplicações dos óxidos metálicos ancorados à superfície da sílica são descritas, tais como adsorventes seletivos, em processos de pré-concentração, como materiais de recheio para uso em HPLC, suporte para imobilização de enzimas, eletrodos amperométricos, sensores e biossensores.
\end{abstract}

In the highly dispersed $\mathrm{M}_{\mathrm{x}} \mathrm{O}_{\mathrm{y}}$ monolayer film on a porous $\mathrm{SiO}_{2}$ surface, denoted as $\mathrm{SiO}_{2} /$ $\mathrm{M}_{\mathrm{x}} \mathrm{O}_{\mathrm{y}}$, the Si-O-M covalent bond formed on the $\mathrm{SiO}_{2}$ surface restricts the mobility of the attached oxide resulting in coordinatively unsaturated metal oxides (LAS) in addition to the Brønsted acid sites (BAS). The BAS arise from the $\mathrm{MOH}$ and $\mathrm{SiOH}$ groups, the latter due to the unreacted silanol groups. As the attached oxides are strongly immobilized on the surface, they are also thermally very stable. The amphoteric character of most of the attached oxides allows the immobilization of various chemical species, acid or bases, resulting in a wide application of these surface modified materials. In this work many of the recent applications of these $\mathrm{M}_{\mathrm{x}} \mathrm{O}_{\mathrm{y}}$ coated silica surfaces are described, such as selective adsorbents, in preconcentration processes, as new packing material for use in HPLC, support for immobilization of enzymes, amperometric electrodes, sensors and biosensors

Keywords: modified silica, monolayer attached metal oxides, preconcentration, modified electrodes, electrochemical sensors, biosensors

\section{Introduction}

The surface of silica gel contains many different types of silanol groups, $\equiv \mathrm{SiOH}$, which can react with reagents such as metal alkoxides or halides. Preparation methods using these reagents in order to obtain active metal oxides, dispersed as monolayer films on the surface of $\mathrm{SiO}_{2}$, have been an area of growing interest in recent years. Experimental procedures, aiming to produce monolayers of the coating metal oxides with thermal stability, have been designed ${ }^{1-13}$. Different from metal oxides supported on solid matrices prepared by impregnation or co-precipitation processes, grafting of the reagent on the solid surface gives rise to oxides whose acidic

e-mail: gushikem@iqm.unicamp.br properties are associated with high thermal and chemical stability, which are not characteristic of the respective oxides in the bulk phase ${ }^{14}$. From the view point of basic research, this procedure is particularly advantageous because formation of a well defined surface species allows a more precise study of the acid-base character of the active sites ${ }^{15,16}$. Although $\mathrm{SiO}_{2}$ has been considered as a relatively inert material, surface silanol groups or strained siloxane groups, as stated above, can react according to the following equations:

$$
\begin{aligned}
& \mathrm{m} \equiv \mathrm{SiOH}+\mathrm{MX}_{\mathrm{n}} \rightarrow(\equiv \mathrm{SiO})_{\mathrm{m}} \mathrm{MX}_{\mathrm{n}-\mathrm{m}}+\mathrm{m} \mathrm{HX} \\
& (\equiv \mathrm{Si})_{2} \mathrm{O}+\mathrm{MX}_{\mathrm{n}} \rightarrow \equiv \mathrm{SiX}+\equiv \mathrm{SiOMX}_{\mathrm{n}-1}
\end{aligned}
$$

where $\mathrm{MX}_{\mathrm{n}}$ is an active metal compound and $\equiv \mathrm{SiOH}$ stands for the silanol group. 
Careful hydrolysis of attached metals leads to formation of a bidimensional oxide structure in which the metals are bound to the surface by a $\equiv \mathrm{SiO}-\mathrm{M}$ bond. In this work some features of monolayer attached oxides on a silica gel surface are discussed.

Many of these materials have been designed to satisfy the demands of activity and selectivity in a catalytic system by a thorough control of surface morphology. For this purpose many studies have been carried out, aiming a better understanding of the surface structure of the oxide coated species $^{4,6,17-22}$. Thus, most of the metal oxide coated silica materials, $\mathrm{SiO}_{2} / \mathrm{M}_{\mathrm{x}} \mathrm{O}_{\mathrm{y}}$, have been prepared for using in catalytic reactions ${ }^{3-5,7,10,11,23-26 .}$.

Highly dispersed metal oxides on a porous silica surface are characterized to present coordinatively unsaturated metal oxide (Lewis acid sites, LAS) in addition to the Bronsted acid sites (BAS), mainly due to the MOH groups. These LAS or BAS can adsorb many molecular species which can be immobilized by covalent bonding or electrostatic interaction. The preparation procedures, properties and applications of these species immobilized on the $\mathrm{SiO}_{2} / \mathrm{M}_{\mathrm{x}} \mathrm{O}_{\mathrm{y}}$ surface, apart from applications in catalytic reactions, are described in this work. We aim to give an overview on new applications of these materials in various fields such as selective adsorbents, enzyme immobilization supports, new packing materials for HPLC columns, carbon paste modified electrodes, electrochemical sensors and biosensors.

\section{Preparation and Characteristics of Oxide Monolayers}

Supported active oxides are prepared as mentioned above by a careful hydrolysis of $\equiv \mathrm{SiOMX}_{\mathrm{n}-1}$ according to the following reaction equations:

$(\equiv \mathrm{SiO})_{\mathrm{m}} \mathrm{MX}_{\mathrm{n}-\mathrm{m}}+(\mathrm{n}-\mathrm{m}) \mathrm{H}_{2} \mathrm{O} \rightarrow(\equiv \mathrm{SiO})_{\mathrm{m}} \mathrm{M}(\mathrm{OH})_{\mathrm{n}-\mathrm{m}}$

$+(\mathrm{n}-\mathrm{m}) \mathrm{HX}$

and

$\equiv \mathrm{SiOMX}_{\mathrm{n}-1}+(\mathrm{n}-1) \mathrm{H}_{2} \mathrm{O} \rightarrow \equiv \operatorname{SiOM}(\mathrm{OH})_{\mathrm{n}-1}+$ (n-1) HX

It is supposed that the metal oxides form a complete and coherent layer. However in no instance, in the various examples cited in the literature, is the surface of the porous solid entirely coated. For instance, the density of niobium atoms for $\mathrm{Nb}_{2} \mathrm{O}_{5}$ coated on a $\mathrm{SiO}_{2}$ surface 27 , i.e. $\mathrm{SiO}_{2} /$ $\mathrm{Nb}_{2} \mathrm{O}_{5}$, is 1.7 atoms $\mathrm{nm}^{-2}$ while complete coverage ${ }^{28}$ requires 2.2 atoms $\mathrm{nm}^{-2}$. Since in most cases the porous solid specific surface areas decrease after the coating treatment, it is not difficult to conceive that the finest pores remain untouched or blocked. In order to assure complete surface coverage, the treatment of the solid surface, i.e., the reactions described by equations 1-4, can be repeated. However, treatment of the solid by successive coating of the porous surface may result in agglomeration of the particles.

\section{Thermal Stability}

The mobility of the oxides on the surface under thermal treatment depends on the particular metal, i.e. of the Si-O$\mathrm{M}$ energy bond. An indication of how mobile the metal particles are on the surface is given by XPS measurements. The results are presented in Table 1 .

Table 1. X-Ray photoelectron spectroscopy data for $\mathrm{SiO}_{2} / \mathrm{M}_{\mathrm{x}} \mathrm{O}_{\mathrm{y}}$.

\begin{tabular}{cccc}
\hline $\mathrm{SiO}_{2} / \mathrm{M}_{\mathrm{x}} \mathrm{O}_{\mathrm{y}}$ & Temperature $/ \mathrm{K}$ & $\begin{array}{c}\text { Atomic Ratio } \\
\mathrm{M} / \mathrm{Si}\end{array}$ & $\begin{array}{c}\text { Binding } \\
\text { Energy } / \mathrm{eV}\end{array}$ \\
\hline $\mathrm{SiO}_{2} / \mathrm{Sb}_{2} \mathrm{O}_{5}$ & 423 & 0.032 & $540.6^{\mathrm{a}}$ \\
& 1073 & 0.036 & 541.0 \\
$\mathrm{SiO}_{2} / \mathrm{Nb}_{2} \mathrm{O}_{5}$ & 1373 & 0.040 & 541.1 \\
& 423 & 0.032 & $210.1^{\mathrm{b}}, 207.3^{\mathrm{c}}$ \\
& 1273 & 0.037 & $210.0,207.3$ \\
$\mathrm{SiO}_{2} / \mathrm{TiO}_{2}$ & 473 & 0.030 & $209.9,207.2$ \\
& 673 & 0.088 & $458.7^{\mathrm{d}}$ \\
& 973 & 0.082 & 458.7 \\
$\mathrm{SiO}_{2} / \mathrm{Al}_{2} \mathrm{O}_{3}$ & 1273 & 0.065 & 458.7 \\
& 423 & 0.045 & 458.7 \\
& 573 & 2.51 & $74.7 \mathrm{e}$ \\
& 873 & 2.29 & 74.9 \\
& 1173 & 2.87 & 75.1 \\
$\mathrm{a}_{3} \mathrm{~b} 3 \mathrm{~d}_{3 / 2},{ }^{\mathrm{c}} 3 \mathrm{~d}_{5 / 2},{ }^{\mathrm{d}} 2 \mathrm{p}_{3 / 2},{ }^{\mathrm{e}} 2 \mathrm{p}$ & 2.61 & 75.2 \\
\end{tabular}

For $\mathrm{SiO}_{2} / \mathrm{Sb}_{2} \mathrm{O}_{5}$ and $\mathrm{SiO}_{2} / \mathrm{Nb}_{2} \mathrm{O}_{5}$, heat treatments of the samples down to $1373 \mathrm{~K}$, in the first case, and $1273 \mathrm{~K}$, in the second case, practically do not change the atomic ratio while for $\mathrm{SiO}_{2} / \mathrm{TiO}_{2}$, the atomic ratio decreases from 0.082 down to 0.045 between $673 \mathrm{~K}$ and $1273 \mathrm{~K}$. Mobility of titanium oxide on the surface is therefore considerable if compared to that observed for antimony and niobium oxides. Diffusion of titanium into the matrix or agglomeration into larger particles may be occurring in this case. Bulk phase binding energies of the metals in the oxides are (in eV): $\mathrm{Sb}_{2} \mathrm{O}_{5}, 3 \mathrm{~d}_{3 /}$ ${ }_{2}=540.5^{29,30} ; \mathrm{Nb}_{2} \mathrm{O}_{5}, 3 \mathrm{~d}_{3 / 2}=210.2$ and $3 \mathrm{~d}_{5 / 2}=207.4^{31} ; \mathrm{TiO}_{2}$ (rutile or anatase), $2 \mathrm{p}_{3 / 2}=459.0^{32}$. Comparing these results with those of the metals in the coating oxides, only $\mathrm{Sb}(\mathrm{V})$, $\mathrm{Nb}(\mathrm{V})$ or $\mathrm{Ti}(\mathrm{IV})$ are detected. In every case the bulk phase oxides under heat treatment undergo phase transformations or chemical transformations at higher temperatures. For instance, the $\mathrm{Sb} 3 \mathrm{~d}_{3 / 2}$ binding energy of $\mathrm{Sb}_{2} \mathrm{O}_{5}$ heat treated at $1373 \mathrm{~K}$ is the same as that presented by $\mathrm{Sb}_{2} \mathrm{O}_{3}{ }^{32}$, indicating a reduction of $\mathrm{Sb}(\mathrm{V})$ to $\mathrm{Sb}(\mathrm{III})$ at this temperature. For $\mathrm{SiO}_{2} /$ 
$\mathrm{Nb}_{2} \mathrm{O}_{5}$ heat treated at this temperature, no decomposition of $\mathrm{Nb}(\mathrm{V})$ was observed ${ }^{27}$.

Bulk amorphous phase $\mathrm{Nb}_{2} \mathrm{O}_{5}$ under heat treatment becomes crystalline at $c a .773 \mathrm{~K}^{33}$ while $\mathrm{SiO}_{2} / \mathrm{Nb}_{2} \mathrm{O}_{5}$ at this temperature is amorphous, as shown in Figure 1(a). The $\mathrm{X}$-ray diffraction patterns are the same upon heating the sample up to $1273 \mathrm{~K}$, Figures 1(b) and 1(c), but above this temperature, more precisely at $1573 \mathrm{~K}$, Figure 1(e), the material becomes crystalline, with separation of the phases and, according to the diffraction peaks, into $\mathrm{H}-\mathrm{Nb}_{2} \mathrm{O}_{5}$ and crystalline $\mathrm{SiO}_{2}$. An important conclusion taken from this experiment is that $\mathrm{Nb}_{2} \mathrm{O}_{5}$ is strongly attached on the silica surface and, thus, only at higher temperatures can the dispersed oxides move and agglomerate to form crystalline particles ${ }^{27}$. For $\mathrm{SiO}_{2} / \mathrm{Al}_{2} \mathrm{O}_{3},{ }^{27} \mathrm{Al}$ NMR spectroscopy detected two species for samples heated between 423 and $1023 \mathrm{~K}, \mathrm{Al}_{\text {oct }}\left(\mathrm{SiO}_{4}\right)_{6}(\sim 10 \mathrm{ppm})$ and $\mathrm{Al}_{\text {tetr }}\left(\mathrm{SiO}_{4}\right)_{4}(\sim 55$ ppm). A third one was observed after higher heating temperature $(>1173 \mathrm{~K})$ due to $\mathrm{Al}_{\text {tbp }}\left(\mathrm{SiO}_{4}\right)_{5}(\sim 40 \mathrm{ppm})$. These observed changes of the ${ }^{27} \mathrm{Al}$ NMR spectra are due to the phase separation of $\mathrm{Al}_{2} \mathrm{O}_{3}$ on the surface ${ }^{34}$.

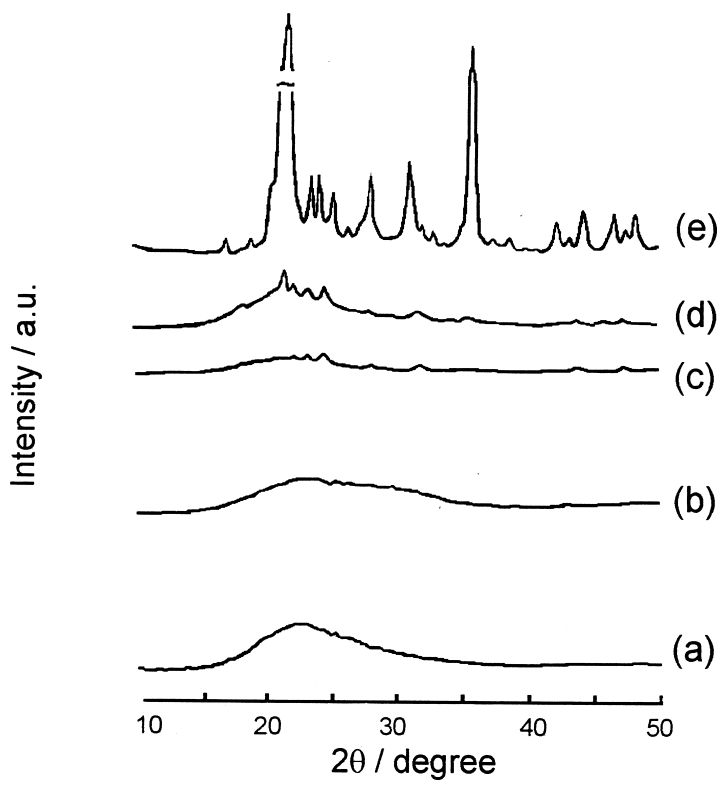

Figure 1. XRD patterns of $\mathrm{SiO}_{2} / \mathrm{Nb}_{2} \mathrm{O}_{5}$ calcined at (a) 423, (b) 773 , (c) 1273, (d) 1473, (e) $1573 \mathrm{~K}$.

\section{Acidic and Basic Properties}

In most cases the attached oxides retain the acid-base properties presented by the corresponding oxides in bulk phase. However, the nature of the acid-base sites can be very different in the case of the highly dispersed oxides.

Assuming that the oxides uniformly cover the porous surface, the average metal atom density, $\delta$, on the surface is given by $\delta=N f \times N / S_{B E T}$, where $N f$ is the quantity of metal atoms (in mol g ${ }^{-1}$ ) in the material, $\mathrm{N}$ is Avogadro's number and $\mathrm{S}_{\mathrm{BET}}$ is the specific surface area (in $\mathrm{nm}^{2} \mathrm{~g}^{-1}$ ). In Table 2 the values of $\delta$ and the respective average interatomic distances, 1 , for some materials are presented.

Table 2. Calculated surface attached metal densities, $\delta$, and the respective interatomic distances, 1 , for some materials.

\begin{tabular}{lccc}
\hline & S/atoms $\mathrm{nm}^{-2}$ & $1 / \mathrm{nm}$ & Ref. \\
\hline $\mathrm{SiO}_{2} / \mathrm{Nb}_{2} \mathrm{O}_{5}$ & 1.7 & 0.76 & 27 \\
$\mathrm{SiO}_{2} / \mathrm{Sb}_{2} \mathrm{O}_{5}$ & 0.65 & 1.2 & 36 \\
$\mathrm{SiO}_{2} / \mathrm{TiO}_{2}$ & 2.2 & 0.67 & 12 \\
$\mathrm{SiO}_{2} / \mathrm{ZrO}_{2}$ & 0.65 & 1.2 & 35 \\
$\mathrm{SiO}_{2} / \mathrm{SnO}_{2}$ & 0.32 & 1.8 & 37 \\
\hline
\end{tabular}

The main characteristic of these submonolayer oxides is that the atoms on the surface are separated sufficiently to allow interaction between them and, thus, they are coordinatively unsaturated. For instance, pyrochlore $\mathrm{Sb}_{2} \mathrm{O}_{5}$ (crystalline oxide) shows only Bronsted acid sites ${ }^{38}$ while $\mathrm{SiO}_{2} / \mathrm{Sb}_{2} \mathrm{O}_{5}(\delta=0.65)$ also shows, in addition to BAS (py $19 \mathrm{~b}$ mode at $1546 \mathrm{~cm}^{-1}$ ), Lewis acid sites, LAS (py 8a mode at $1617 \mathrm{~cm}^{-1}$ and $19 \mathrm{~b}$ at $\left.1456 \mathrm{~cm}^{-1}\right)^{36}$. Such differences between the bulk structure and the highly dispersed form of antimony (V) oxide are due to the absence of a crystalline lattice in $\mathrm{SiO}_{2} / \mathrm{Sb}_{2} \mathrm{O}_{5}$. Interaction of a base with LAS can occur, as shown in the Scheme 1.

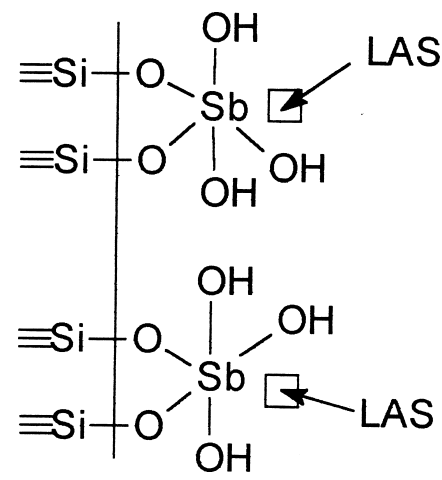

Scheme 1. Structure proposed for $\mathrm{Sb}$ on the surface of $\mathrm{SiO}_{2}$. In this scheme, $\mathrm{Sb}$ ions are represented as coordinatively unsaturated and this is responsible for the Lewis acidity.

Generation of acid sites is also possible in aqueous solution on the surface of $\mathrm{SiO}_{2} / \mathrm{M}_{\mathrm{x}} \mathrm{O}_{\mathrm{y}}$. Many of the oxides have an amphoteric character. At solution $\mathrm{pH}$ below the point of zero charge (pzc), they can adsorb negatively charged species according to two possible reactions ${ }^{39-41}$ :

a) $\mathrm{MOH}+\mathrm{H}^{+}+\mathrm{L}^{-} \rightarrow \mathrm{M}^{+} \mathrm{L}^{-}+\mathrm{H}_{2} \mathrm{O}$

or

b) $\mathrm{MOH}+\mathrm{H}^{+}+\mathrm{L}^{-} \rightarrow \mathrm{MOH}_{2}^{+} \mathrm{L}^{-}$ 
At solution $\mathrm{pH}$ above (pzc) they can adsorb positively charged species:

c) $\mathrm{z} \mathrm{MOH}+\mathrm{M}_{\mathrm{z}}^{+}+\mathrm{OH}^{-} \rightarrow\left(\mathrm{MO}^{-}\right)_{\mathrm{z}} \mathrm{M}_{\mathrm{z}}^{+}+\mathrm{H}_{2} \mathrm{O}$

where MOH stands for the metal oxide grafted on the silica surface

As an example of anionic adsorption, as shown in equation 5 and 6 , the interaction of the anionic complex $\left[\mathrm{Fe}(\mathrm{CN})_{6}\right]^{4-}$ with $\mathrm{SiO}_{2} / \mathrm{TiO}_{2}$ and $\mathrm{SiO}_{2} / \mathrm{ZrO}_{2}$ can be cited. The adherence of this species on the substrate surface is predominantly due to an ion pair interaction (equation 6). The infrared active $\mathrm{CN}$ stretching mode for $\mathrm{K}_{4}\left[\mathrm{Fe}(\mathrm{CN})_{6}\right]$ is observed at $2041 \mathrm{~cm}^{-1}\left(\mathrm{~T}_{1 \mathrm{u}}\right.$ mode; $\mathrm{O}_{\mathrm{h}}$ symmetry) and, for the adsorbed species on $\mathrm{SiO}_{2} / \mathrm{TiO}_{2}$ or $\mathrm{SiO}_{2} / \mathrm{ZrO}_{2}$ surfaces, it is not shifted towards higher frequency as normally expected for M-NC bond formation ${ }^{42}$ nor is it split into $2 \mathrm{~A}_{1}+\mathrm{E}\left(\mathrm{C}_{4 \mathrm{v}} \text { symmetry }\right)^{43,44}$.

It is also possible to graft phosphate groups to the silica gel surface coated with titanium oxide:

$(\equiv \mathrm{SiO})_{2} \mathrm{Ti}(\mathrm{OH})_{2}+\mathrm{H}_{3} \mathrm{PO}_{4} \rightarrow(\equiv \mathrm{SiO})_{2} \mathrm{Ti}\left(\mathrm{OPO}_{3} \mathrm{H}\right)_{2}$ $+2 \mathrm{H}_{2} \mathrm{O}$

This new material was used to accumulate positively charged mediators such as Meldola's Blue or methylene blue, by ion exchange with the protons of either the phosphate groups or the hydroxyl groups on the titanium atom ${ }^{45-48}$. Experimental conditions were optimised to give the highest mediation efficiency together with the best immobilization quality.

The $[\mathrm{Co}(\text { sepulchrate })]^{3+}$ complex immobilized on the surface of silica gel, $\mathrm{SiO}_{2} / \mathrm{ZrO}_{2}$ and $\mathrm{SiO}_{2} / \mathrm{ZrO}_{2} /$ phosphate, shows electrochemical responses due to the redox process of the $\mathrm{Co}(\mathrm{III}) / \mathrm{Co}$ (II) couple ${ }^{49}$. Acidity of the immobilized zirconium phosphate is higher than that of other matrices. Therefore, a larger amount of the cobalt complex was found and the redox potential of the $\mathrm{Co}$ (III)/Co(II) couple was less affected by changes in the $\mathrm{pH}$ values of the solutions. The electrochemical behaviour of the adsorbed complex on the matrices is affected as the $\mathrm{pH}$ of the solutions, as well as the nature and concentration of the supporting electrolyte, are changed.

\section{Reaction of the Adsorbed Species}

Reactions of the adsorbed species giving rise to a new phase on the surface is also possible. For example, strongly adhered $\left[\mathrm{Fe}(\mathrm{CN})_{6}\right]^{4-}$ anion on a $\mathrm{SiO}_{2} / \mathrm{M}_{\mathrm{x}} \mathrm{O}_{\mathrm{y}}$ surface, $\left(\mathrm{MOH}_{2}^{+}\right)_{4}\left[\mathrm{Fe}(\mathrm{CN})_{6}\right]^{4-}$, can react with a series of metal ions $\mathrm{Y}^{\mathrm{n}+}$ forming the well known mixed valence complexes, $\left(\mathrm{M}^{+}\right)_{(4-\mathrm{n})}\left\{\mathrm{Y}\left[\mathrm{Fe}(\mathrm{CN})_{6}\right]\right\}^{(4-\mathrm{n})-}$. The same surface species are formed when $\left(\mathrm{MO}^{-}\right)_{n} \mathrm{Y}^{\mathrm{n}+}$ reacts with $\left[\mathrm{Fe}(\mathrm{CN})_{6}\right]^{4-}$ in acid solution. The reactions that describe the formation of the complexes are:

$\left(\mathrm{MOH}_{2}^{+}\right)_{4}\left[\mathrm{Fe}(\mathrm{CN})_{6}\right]^{4-}+\mathrm{Y}^{\mathrm{n}+} \rightarrow$
$\left(\mathrm{MOH}_{2}^{+}\right)_{(4-\mathrm{n})}\left\{\mathrm{Y}\left[\mathrm{Fe}(\mathrm{CN})_{6}\right]\right\}^{(4-\mathrm{n})-}+\mathrm{nMOH}_{2}^{+}$

In equation 9, the adsorbed hexacyanoferrate complex reacts with a metal ion and in the second case, equation 10 ,

$\left(\mathrm{MO}^{-}\right)_{\mathrm{n}} \mathrm{Y}^{\mathrm{n}+}+\left[\mathrm{Fe}(\mathrm{CN})_{6}\right]^{4-}+2 \mathrm{n} \mathrm{H}^{+} \rightarrow$
$\left(\mathrm{MOH}_{2}^{+}\right)_{(4-\mathrm{n})}\left\{\mathrm{Y}\left[\mathrm{Fe}(\mathrm{CN})_{6}\right]\right\}^{(4-\mathrm{n})-}$

the adsorbed metal ion reacts with the hexacyanoferrate ion at the solid-surface interface, resulting in the same mixed valence complex as in equation 9 .

Evidence that supports formation of such structured complexes on the surface is given by the values of the midpoint potential, obtained from cyclic voltammetry measurements by using carbon paste electrodes made with these materials ${ }^{37,43-53}$. Table 3 contains the midpoint redox potentials, $\mathrm{E}_{\mathrm{m}}\left[\mathrm{E}_{\mathrm{m}}=\left(\mathrm{E}_{\mathrm{pa}}+\mathrm{E}_{\mathrm{pc}}\right) / 2\right.$; where $\mathrm{E}_{\mathrm{pa}}$ and $\mathrm{E}_{\mathrm{pc}}$ are the anodic and cathodic peak potentials respectively].

Table 3. Calculated midpoint redox potentials of modified electrodes with $\mathrm{SiO}_{2} / \mathrm{M}_{\mathrm{x}} \mathrm{O}_{\mathrm{y}}\left\{\mathrm{Y}\left[\mathrm{Fe}(\mathrm{CN})_{6}\right]\right\}^{1-/ 2-} ; \mathrm{Y}=\mathrm{Co}, \mathrm{Ni}, \mathrm{Cu}$.

\begin{tabular}{lcc}
\hline Material & $\mathrm{E}_{\mathrm{m}} / \mathrm{V}$ vs $\mathrm{SCE}^{*}$ & Ref. \\
\hline $\mathrm{SiO}_{2} / \mathrm{SnO}_{2}\left[\mathrm{Fe}(\mathrm{CN})_{6}\right]^{3-/ 4-}$ & 0.22 & 37 \\
$\mathrm{SiO}_{2} / \mathrm{SnO}_{2}\left\{\mathrm{Co}\left[\mathrm{Fe}(\mathrm{CN})_{6}\right]\right\}^{1-/ 2-}$ & 0.33 & 52 \\
$\mathrm{SiO}_{2} / \mathrm{SnO}_{2}\left\{\mathrm{Ni}\left[\mathrm{Fe}(\mathrm{CN})_{6}\right]\right\}^{1-/ 2-}$ & 0.46 & 37 \\
$\mathrm{SiO}_{2} / \mathrm{SnO}_{2}\left\{\mathrm{Cu}\left[\mathrm{Fe}(\mathrm{CN})_{6}\right]\right\}^{1-/ 2-}$ & 0.62 & 50 \\
$\mathrm{SiO}_{2} / \mathrm{TiO}_{2}\left[\mathrm{Fe}(\mathrm{CN})_{6}\right]^{3-/ 4-}$ & 0.17 & 43 \\
$\mathrm{SiO}_{2} / \mathrm{TiO}_{2}\left\{\mathrm{Ni}\left[\mathrm{Fe}(\mathrm{CN})_{6}\right]\right\}^{1-/ 2-}$ & 0.62 & 51 \\
$\mathrm{SiO}_{2} / \mathrm{TiO}_{2}\left\{\mathrm{Cu}\left[\mathrm{Fe}(\mathrm{CN})_{6}\right]\right\}^{1-/ 2-}$ & 0.76 & 51 \\
$\mathrm{SiO}_{2} / \mathrm{ZrO}_{2}[\mathrm{Fe}(\mathrm{CN}) 6]^{3-/ 4-}$ & 0.21 & 44,53 \\
$\mathrm{SiO}_{2} / \mathrm{ZrO}_{2}\left\{\mathrm{Cu}\left[\mathrm{Fe}(\mathrm{CN})_{6}\right]\right\}^{1-/ 2-}$ & 0.69 & 53 \\
\hline *In $1 \mathrm{~mol} \mathrm{~L}^{-1} \mathrm{KNO}_{3}$ supporting electrolyte solutions.
\end{tabular}

It is shown that $\mathrm{E}_{\mathrm{m}}$ depends on the nature of the metal $\mathrm{Y}$ in the mixed valence compound, as is observed for bulk phase complexes. Also it is shown that for a given mixed valence complex formed on the surface, $\mathrm{E}_{\mathrm{m}}$ depends on the nature of the supporting electrolyte. For instance, in $1 \mathrm{~mol} \mathrm{~L}^{-1}$ $\mathrm{NaNO}_{3}, \mathrm{KNO}_{3}$ and $\mathrm{NH}_{4} \mathrm{NO}_{3}$, the $\mathrm{E}_{\mathrm{m}}$ found (against SCE electrode $)^{37}$, using the $\mathrm{SiO}_{2} / \mathrm{SnO}_{2} /\left\{\mathrm{Ni}\left[\mathrm{Fe}(\mathrm{CN})_{6}\right]\right\}$ carbon paste electrode, are: $0.35,0.46$ and $0.47 \mathrm{~V}$, respectively. Since the surface mixed valence complex has a zeolitic type structure, such dependence is explained on the basis of the following mechanism proposed for the redox reaction:

$\mathrm{SnOH}_{2}^{+}\left\{\mathrm{Ni}\left[\mathrm{Fe}(\mathrm{CN})_{6}\right]\right\}^{-}+\mathrm{s}^{+}+\mathrm{e}^{-} \rightleftharpoons$

$\mathrm{SnOH}_{2}{ }^{+}\left\{\mathrm{sNi}\left[\mathrm{Fe}(\mathrm{CN})_{6}\right]\right\}^{-}$

where in the redox process the supporting electrolyte $\mathrm{s}^{+}$must diffuse into or move out of the surface structured complex. 
The hydrated ionic sizes of the ions are (in $\mathrm{nm}$ ): $\mathrm{Li}^{+}=0.47$, $\mathrm{Na}^{+}=0.36, \mathrm{~K}^{+} \sim \mathrm{NH}_{4}^{+}=0.24^{54}$. Since the channel diameter of the surface complex is $0.31 \mathrm{~nm}^{55}$, ions having nearly the same hydrated radio $\left(\mathrm{NH}_{4}{ }^{+}\right.$and $\left.\mathrm{K}^{+}\right)$have the same midpoint potential and for $\mathrm{Na}^{+}$, that presents a larger size, the potential is higher. When using $\mathrm{Li}^{+}$as the supporting electrolyte, no redox peak is observed because it can not pass through the cavity of the surface complex. Similar results have been observed with other modified mixed valence complexes adsorbed on $\mathrm{SiO}_{2} / \mathrm{M}_{\mathrm{x}} \mathrm{O}_{\mathrm{y}}{ }^{37,43-53}$.

An interesting example of reactivity of adsorbed species is a property of the adsorbed complex $\mathrm{SiO}_{2} / \mathrm{ZrO}_{2} /$ $\left[\mathrm{Ru}(\text { edta })\left(\mathrm{H}_{2} \mathrm{O}\right)\right]^{-}$(Scheme 2$)^{56}$. The adsorbed coordinated $\mathrm{H}_{2} \mathrm{O}$ is kinetically labile due to hydrogen bonding and can be easily replaced by a ligand $\mathrm{L}$. If the basicity of ligand $\mathrm{L}$ changes, we observe that the midpoint potential of the reaction

$\left[\mathrm{Ru}^{\mathrm{III}}-\mathrm{L}\right]+\mathrm{e}^{-} \rightleftharpoons\left[\mathrm{Ru}^{\mathrm{II}}-\mathrm{L}\right]$

depends on the basicity of the ligand L i.e., the more basic the ligand, the more positive will be the midpoint potential (Table 4 ).

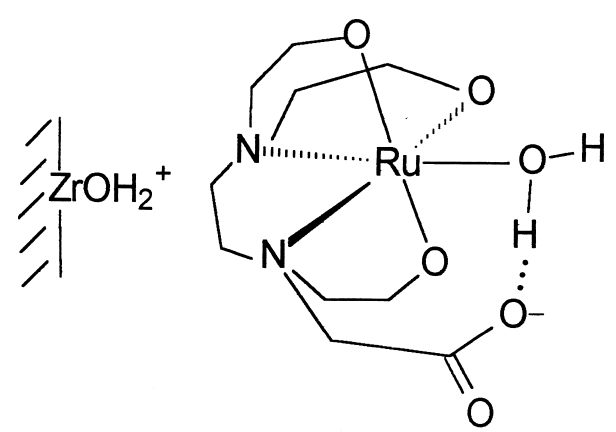

Scheme 2. $\left[\mathrm{Ru}\left(\text { edta) } \mathrm{H}_{2} \mathrm{O}\right)\right]^{-}$adsorbed on $\equiv \mathrm{ZrOH} ; \mathrm{N}-\mathrm{N}=\mathrm{NCH}_{2} \mathrm{CH}_{2} \mathrm{~N}$ and $\mathrm{N}-\mathrm{O}=\mathrm{NCH}_{2} \mathrm{COO}^{-}$.

Table 4. Midpoint potentials for $\mathrm{ZrOH}_{2}^{+} /[\mathrm{Ru}(\text { edta }) \mathrm{L}]^{-}$

\begin{tabular}{cc}
\hline $\mathrm{L}$ & $\mathrm{E}_{\mathrm{m}}{ }^{* / m V}$ vs SCE \\
\hline $\mathrm{H}_{2} \mathrm{O}$ & -290 \\
$\mathrm{SCN}^{-}$ & -200 \\
Pyridine & -180 \\
4-Cyanopyridine & -80 \\
Pyrazine & -50 \\
\hline
\end{tabular}

In certain cases molecules can be adsorbed onto the substrate surface by a chemical bonding, as is observed for ascorbic acid on $\mathrm{SiO}_{2} / \mathrm{Nb}_{2} \mathrm{O}_{5}{ }^{57}$. When dipping the solid into a solution containing ascorbic acid, the solid turns yellow immediately, presumably due to the formation of the surface complex. The adsorbed ascorbic acid can efficiently reduce some metal ions at the solid-solution interface. The reduction yield observed for some metal ions is: $\mathrm{Fe}(\mathrm{III})=95.4 \pm 2.2 \%$,
$\mathrm{Cr}(\mathrm{VI})=99.7 \pm 0.2 \%$ and $\mathrm{Cu}(\mathrm{II})=89.3 \pm 1.6 \% 57$. Molecules having a carboxylic acid radical are easily adsorbed on a $\mathrm{SiO}_{2} / \mathrm{Nb}_{2} \mathrm{O}_{5}$ surface due to $\mathrm{Nb}-\mathrm{OOC}$ - bond formation ${ }^{57,58}$. Scheme 3 illustrates how ferrocenecarboxylic acid is bound to the $\mathrm{SiO}_{2} / \mathrm{Nb}_{2} \mathrm{O}_{5}$ surface ${ }^{59}$.

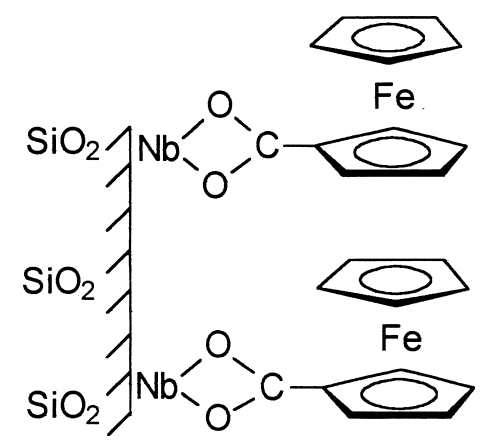

Scheme 3. Scheme proposed for binding of ferrocenecarboxylic acid onto the $\mathrm{SiO}_{2} / \mathrm{Nb}_{2} \mathrm{O}_{5}$ surface. (Reproduction from Ref. 59 by permission of Elsevier Science B.V.).

The material $\mathrm{SiO}_{2} / \mathrm{TiO}_{2}$ is very efficient as an adsorbent because it is very porous while the bulk phase is normally non-porous. The active sites $\equiv \mathrm{TiOH}$ groups in the former case are distributed over a narrower size pores, and thus, they are more available. When $\mathrm{SiO}_{2} / \mathrm{TiO}_{2}$ was immersed in $\mathrm{H}_{2} \mathrm{O}_{2}$ solution, the coated $\mathrm{Ti}(\mathrm{IV})$ oxide exhibited coordination properties. The appearance of an orange color on the solid surface in contact with hydrogen peroxide is a result of the coordination of $\mathrm{H}_{2} \mathrm{O}_{2}$ with the Lewis acid site ${ }^{60}$. The maximum sorption capacity, 1.2 molecule $\mathrm{nm}^{-2}$, was achieved in solution at $\mathrm{pH} 3$. The adsorbed hydrogen peroxide retained its oxidation capacity for several weeks. After the sorption of the $\mathrm{H}_{2} \mathrm{O}_{2}$ by $\mathrm{SiO}_{2} / \mathrm{TiO}_{2}$, formation of super oxide radicals was observed, presumably resulting from peroxide decomposition.

When the material $\mathrm{SiO}_{2} / \mathrm{Sb}_{2} \mathrm{O}_{5}$ was immersed in an aqueous $\mathrm{Fe}^{3+}$ solution, it showed two remarkable changes: an increase of the $\mathrm{Sb}: \mathrm{Si}$ atomic ratio, due to the enrichment of the amount of $\mathrm{Sb}(\mathrm{V})$ content on the matrix surface, and formation of a new phase, $\mathrm{FeSbO}_{4}$, as established by the studies of X-ray photoelectron spectroscopy and Mössbauer spectroscopy, respectively 61 . With the intention of understanding the mechanism of formation of the $\mathrm{FeSbO}_{4}$ phase, two different routes for the preparation of the material were studied: (i) $\mathrm{SiO}_{2} / \mathrm{Sb}_{2} \mathrm{O}_{5}$ was immersed in an aqueous solution of $\mathrm{Fe}^{3+}$, followed by thermal treatment at $423 \mathrm{~K}$ or (ii) $\mathrm{SiO}_{2} / \mathrm{Sb}_{2} \mathrm{O}_{5}$ was immersed in a solution of $\mathrm{Fe}(\mathrm{CO})_{5}$ in $\mathrm{CCl}_{4}$ followed by further hydrolysis and heat treatment at $1073 \mathrm{~K}^{62,63}$. In both cases an excess of $\mathrm{Sb}(\mathrm{V})$ was found on the surface, in relation to Fe(III). This fact was interpreted as a result of the migration of $\mathrm{Sb}(\mathrm{V})$ from 
the internal surface to the external surface when method (i) was used and as being due to migration of $\mathrm{Fe}$ (III) in the opposite direction when the material was obtained by method (ii).

\section{Applications of $\mathrm{SiO}_{2} / \mathrm{M}_{x} \mathrm{O}_{y}$}

\subsection{In preconcentration processes and chemical analyses}

$\mathrm{SiO}_{2} / \mathrm{MO}_{2}(\mathrm{M}=\mathrm{Ti}, \mathrm{Zr})$ selectively adsorb $\mathrm{Cr}_{2} \mathrm{O}_{7}{ }^{2-}$ from an acid solution 64,65 :

$\mathrm{MOH}+\mathrm{Cr}_{2} \mathrm{O}_{7}{ }^{2-}+\mathrm{H}^{+} \rightarrow \mathrm{MOH}_{2}^{+}\left[\mathrm{Cr}_{2} \mathrm{O}_{7}{ }^{2-}\right]$

where $\mathrm{MOH}$ stands for hydrated $\mathrm{MO}_{2}$ grafted on the silica surface. This property has been used to preconcentrate and analyse low concentrations of this ion in water ${ }^{66}$.

Adsorption properties of metallic ions, such as cadmium, lead and mercury, on $\mathrm{SiO}_{2} / \mathrm{ZrO}_{2} /$ phosphate were investigated by using the batch system ${ }^{67}$. A selective adsorption towards heavy metals with increasing affinity order $\mathrm{Cd}$ (II) $<\mathrm{Pb}$ (II) $<\mathrm{Hg}$ (II) was observed. A conjugated use of $\mathrm{SiO}_{2} / \mathrm{ZrO}_{2} /$ phosphate and silica modified with n-propylimidazole (SiIm) has been carried out for the separation of heavy-metals, such as cadmium, lead and mercury 68,69

$\mathrm{SiO}_{2} / \mathrm{Al}_{2} \mathrm{O}_{3}$ has been used to adsorb the soluble polyelectrolyte, 3(n-propylpyridinium) chloride silsesquioxane polymer ${ }^{70}$, whose structure is shown in
Scheme 4 . The polymer does not immobilize directly onto $\mathrm{a} \mathrm{SiO}_{2}$ surface because it is highly water soluble. However, $\mathrm{SiO}_{2} / \mathrm{Al}_{2} \mathrm{O}_{3}$ has a monolayer of aluminium oxide which can easily react with the free $\mathrm{SiOH}$ groups of the polymer, resulting in a layer of the polyelectrolyte strongly adhered to the surface by formation of the Al-O-Si bond, illustrated in Scheme 5. The $\mathrm{SiO}_{2} / \mathrm{Al}_{2} \mathrm{O}_{3}$ with the polylectrolyte has a very high ion exchange capacity and has been used in adsorption of metal ions from ethanol solutions ${ }^{71}$.

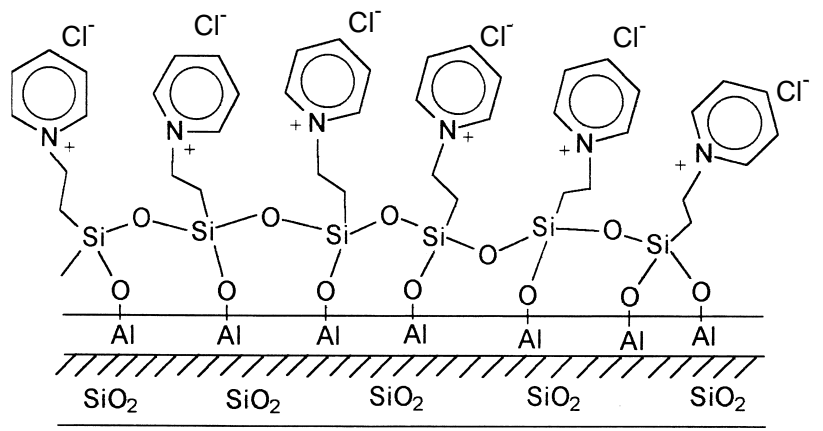

Scheme 5. Scheme proposed for a layer of the polyelectrolyte strongly adhered to the $\mathrm{SiO}_{2} / \mathrm{Al}_{2} \mathrm{O}_{3}$ surface by formation of the Al-O-Si bond.

\subsection{Support for high-performance liquid chromatography}

In high-performance liquid chromatography (HPLC), normally porous $\mathrm{SiO}_{2}$ covered with organofunctional groups has been used as the stationary phase. However, the use of

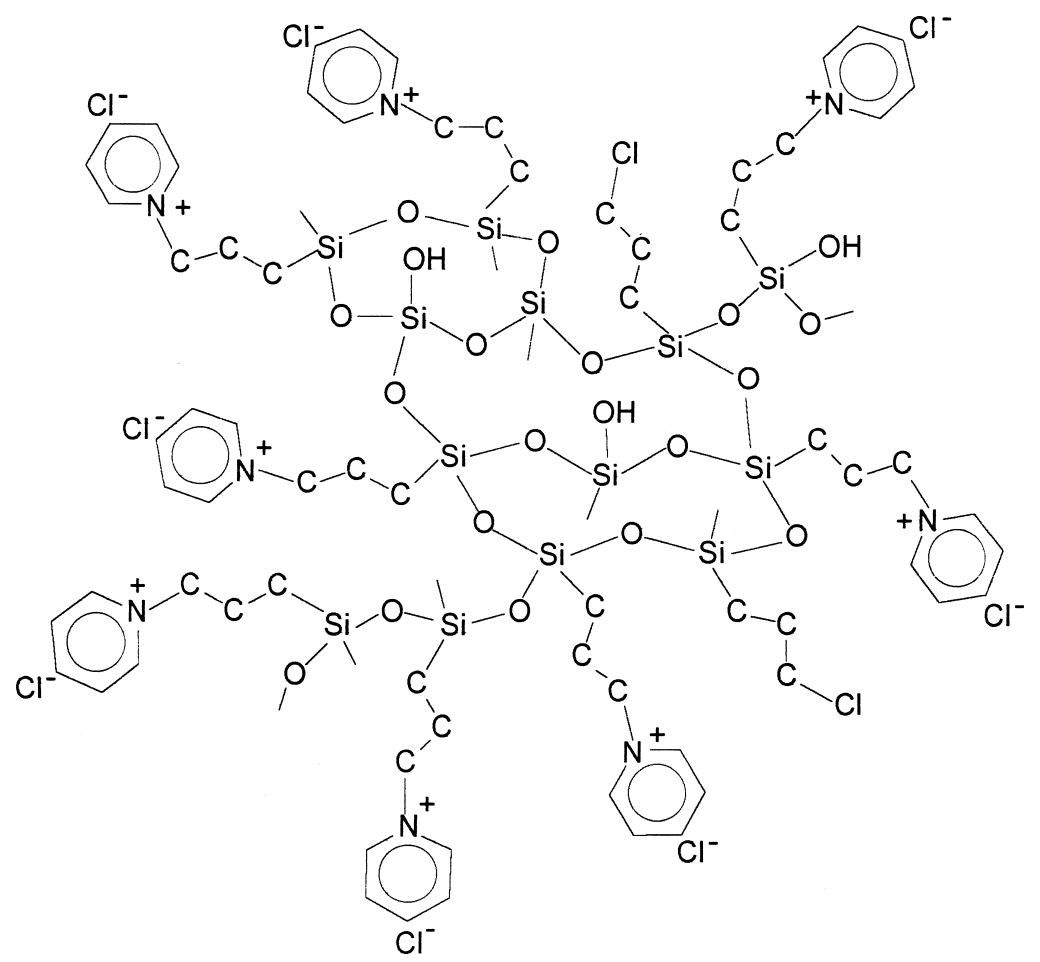

Scheme 4. Structure of soluble polyelectrolyte, 3(n-propylpyridinium) chloride silsesquioxane polymer. 
this modified substrate has limited chemical stability at $\mathrm{pH}$ higher than 7. In addition, silanol groups that were not reacted with organic groups or remained untouched after treatment with end capping reagents, may cause tailing or irreversible adsorption of basic solutes during operation of the column. In recent work, toward overcoming this limitation Collins et al. have coated a $\mathrm{SiO}_{2}$ surface with $\mathrm{ZrO}_{2}$ or $\mathrm{TiO}_{2}$ protective layers (monolayer or submonolayer) by a grafting process and, in a further step, treated this material with organofunctional siloxanes such as polymethylsiloxane (PMOS), followed by $\gamma$ irradiation to promote the cross linking of the organic groups ${ }^{72-76}$. A considerable increase in efficiency and excellent stationary phase stability has been observed when using alkaline mobile phases. Figure 2 shows the performance achieved with $\mathrm{SiO}_{2} / \mathrm{ZrO}_{2} / \mathrm{PMOS}$ irradiated with $\gamma$ radiation. Its stability was measured by plotting the relative efficiency against the column volumes of mobile phase using an $\mathrm{NH}_{3} / \mathrm{NH}_{4}{ }^{+}$buffer $\mathrm{pH} 10$ in $\mathrm{MeOH}$ in the proportion 30:70 $\mathrm{v} / \mathrm{v}^{75}$. Column I refers to $\mathrm{SiO}_{2} / \mathrm{PMOS}$ and column II to $\mathrm{SiO}_{2} / \mathrm{ZrO}_{2} / \mathrm{PMOS}$. It is observed that above 1000 column volumes the efficiency for $\mathrm{SiO}_{2} / \mathrm{ZrO}_{2} / \mathrm{PMOS}$ is about $95 \%$ and for $\mathrm{SiO}_{2} / \mathrm{PMOS}$, is about $75 \%$, of the initially measured efficiencies.

The good results obtained by using $\mathrm{SiO}_{2} / \mathrm{MO}_{2} / \mathrm{PMOS}$ $(\mathrm{M}=\mathrm{Ti}, \mathrm{Zr}$ ) have been attributed to the reduction of the acidic properties of silica through titanization or zirconization, as well as to PMOS chain cross linking, resulting in stationary phases that show significant promise as a support when high $\mathrm{pH}$ mobile phase is required.

\subsection{Electrochemical sensors and biosensors}

Metal oxides coated on silica gel have been used for immobilization of various electron transfer mediator species. Such modified materials are very attractive because they are the basis for developing various sensors and biosensors. Important characteristics of these materials are

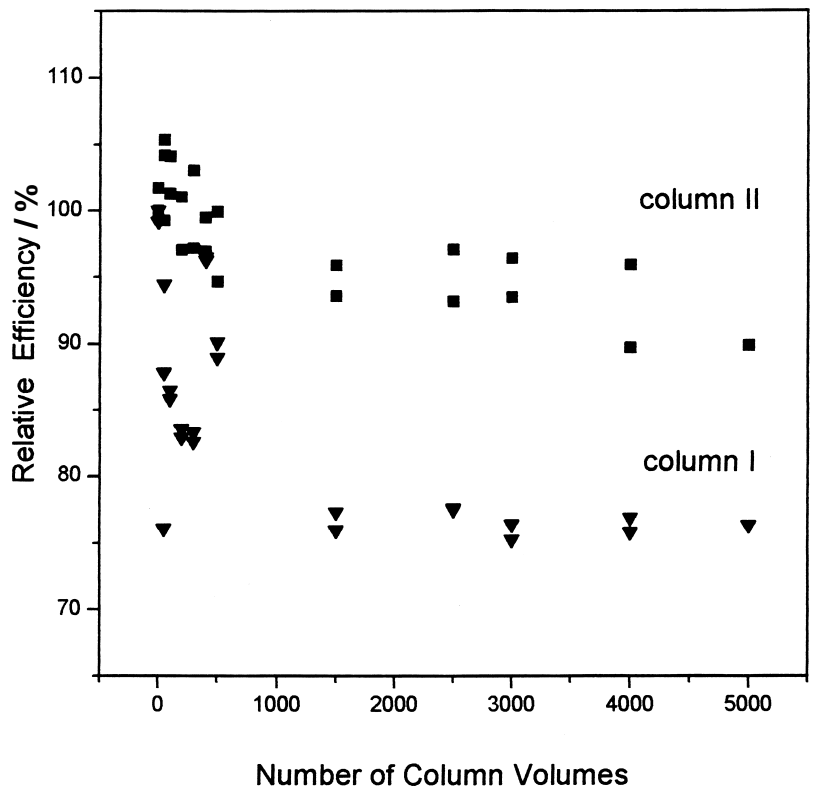

Figure 2. Efficiency $v s$ column volumes using a mobile phase [buffer $\left.\mathrm{NH}_{3} / \mathrm{NH}_{4}{ }^{-}, \mathrm{pH} 10\right]: \mathrm{MeOH}$ in the proportion 30:70 v/v. Column I refers to $\mathrm{SiO}_{2}(\mathrm{PMOS})$ and column II to $\mathrm{SiO}_{2} / \mathrm{ZrO}_{2}$ (PMOS).

high surface area and porosity, very easy procedures for mediator immobilization, preventing leaching from the electrode into the solution, and the mechanical and chemical resistance conferred by the silica matrix.

The interest in silica-modified electrodes with respect to their applications in electroanalysis was recently reviewed by Walcarius ${ }^{77}$. Table 5 presents a short summary of the use of $\mathrm{SiO}_{2} / \mathrm{M}_{\mathrm{x}} \mathrm{O}_{\mathrm{y}}$-containing electrodes for the development of electrochemical sensors and biosensors.

The following overview describes the main uses found for these materials up to now.

\subsubsection{Ascorbic acid sensor}

The hexacyanoferrate ion adsorbed on $\mathrm{SiO}_{2} / \mathrm{ZrO}_{2}$ has been used to quantitatively determine vitamin $\mathrm{C}$ in natural

Table 5. Applications of modified carbon paste electrodes with modified silica in chemical analysis.

\begin{tabular}{|c|c|c|c|c|c|}
\hline Analyte & Modifier [a] & $\begin{array}{c}\text { Detection medium } \\
\text { (pH and concentration) [b] }\end{array}$ & $\begin{array}{c}\text { Method } \\
\left(\mathrm{E}_{\mathrm{apl}} \text { in } \mathrm{mV} \text { vs } \mathrm{SCE}\right)\end{array}$ & Concentration range & Ref. \\
\hline Hydrazine & ST-NiTsPc & 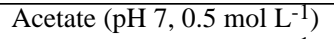 & Amperometry (480) & $1 \times 10^{-4}-6 \times 10^{-4} \mathrm{~mol} \mathrm{~L}^{-1}$ & 80 \\
\hline Cysteine & ST-NiTsPc & Acetate $\left(\mathrm{pH} 2,0.5 \mathrm{~mol} \mathrm{~L}^{-1}\right)$ & Amperometry (500) & $1 \times 10^{-3}-7 \times 10^{-3} \mathrm{~mol} \mathrm{~L}^{-1}$ & 79 \\
\hline Hydrazine & ST-FeTsPc & $\mathrm{KCl}\left(\mathrm{pH} 6,1 \mathrm{~mol} \mathrm{~L}^{-1}\right)$ & Cyclic Voltammetry & & 78 \\
\hline NADH & STPM & Phosphate buffer ( $\mathrm{pH} 7.4$ ) & Amperometry (0) & $1 \times 10^{-5}-5 \times 10^{-5} \mathrm{~mol} \mathrm{~L}^{-1}$ & 45 \\
\hline $\mathrm{O}_{2}$ & $\mathrm{SNb}-\mathrm{CoHMP}$ & $\mathrm{KCl}\left(\mathrm{pH} 6,1 \mathrm{~mol} \mathrm{~L}^{-1}\right)$ & Cyclic Voltammetry & $8.4 \times 10^{-5}-3.9 \times 10^{-4} \mathrm{~mol} \mathrm{~L}^{-1}$ & 58 \\
\hline $\mathrm{O}_{2}$ & $\mathrm{SNb}-\mathrm{CoPP}$ & $\mathrm{KCl}\left(\mathrm{pH} 6,1 \mathrm{~mol} \mathrm{~L}^{-1}\right)$ & Cyclic Voltammetry & $5 \times 10^{-5}-3.4 \times 10^{-4} \mathrm{~mol} \mathrm{~L}^{-1}$ & 58 \\
\hline Glucose & ST-FC-GOD & PIPES (pH 6.8, $\left.0.1 \mathrm{~mol} \mathrm{~L}^{-1}\right)$ & Amperometry (?) & $1 \times 10^{-4}-8 \times 10^{-4} \mathrm{~mol} \mathrm{~L}^{-1}$ & 83 \\
\hline Fructose & STPM-FDH & McIlvaine (pH 4.5) & Amperometry (20) & $1 \times 10^{-4}-7 \times 10^{-4} \mathrm{~mol} \mathrm{~L}^{-1}$ & 46 \\
\hline Salicylate & STPM-SH & Phosphate buffer ( $\mathrm{pH} 7.4$ ) & Amperometry (200) & $1 \times 10^{-5}-6 \times 10^{-5} \mathrm{~mol} \mathrm{~L}^{-1}$ & 47 \\
\hline Phenol & ST-HRP & Phosphate buffer (pH 7) & Amperometry (0) & $1 \times 10^{-5}-5 \times 10^{-5} \mathrm{~mol} \mathrm{~L}^{-1}$ & 84 \\
\hline
\end{tabular}

[a] Abbreviations: $\mathrm{ST}=\mathrm{SiO}_{2} / \mathrm{TiO}_{2} ; \mathrm{STPM}=\mathrm{SiO}_{2} / \mathrm{TiO}_{2} /$ phosphate/Meldola's Blue; $\mathrm{SNb}=\mathrm{SiO}_{2} / \mathrm{Nb}_{2} \mathrm{O}_{5} ; \mathrm{CoHMP}=$ cobalt (II) hematoporphyrin IX; CoPP $=$ cobalt (II) protoporphyrin IX; NiTsPc= nickel tetrasulfophthalocyanine ;FeTsPc $=$ iron tetrasulfophthalocyanine; HRP = horseradish peroxidase; FDH = D-fructose 5-dehydrogenase; GOD = glucose oxidase; $\mathrm{SH}=$ salicylate hydroxylase; [b] Abbreviations: PIPES = 1,4-piperazinediethanesulfonic acid. 
and processed juices, as well as in tablets ${ }^{44}$. The hexacyanoferrate anion can mediate the catalytic oxidation of ascorbic acid at lower potential and thus avoid interference from other species normally present in real samples.

\subsubsection{Dissolved oxygen sensor}

The material $\mathrm{SiO}_{2} / \mathrm{ZrO}_{2} /\left[\mathrm{Ru}(\text { edta })\left(\mathrm{H}_{2} \mathrm{O}\right)\right]^{-}$was used to fabricate an amperometric sensor for determination of dioxygen in natural water ${ }^{56}$. On this electrode surface dissolved $\mathrm{O}_{2}$ is reduced at $-300 \mathrm{mV}$ vs SCE, against -500 $\mathrm{mV}$ on a bare electrode surface. The electrode is very selective and the use of a semi permeable membrane, as used in the Clark electrode, is not necessary in the present case. The lower limit of detectable dissolved oxygen is about $0.5 \mathrm{mg} \mathrm{L}^{-1}$.

Cobalt (II) hematoporphyrin IX or cobalt (II) protoporphyrin IX are adsorbed on $\mathrm{SiO}_{2} / \mathrm{Nb}_{2} \mathrm{O}_{5}$ surface by $\mathrm{Nb}-\mathrm{OOC}$ - chemical bond formation ${ }^{58}$ (Scheme 6). In the presence of dissolved $\mathrm{O}_{2}$, a cathodic peak at $-0.18 \mathrm{~V}$ (vs SCE) is observed. Between pH 4 and 7, the electrode response is not affected, keeping the cathodic potential constant.

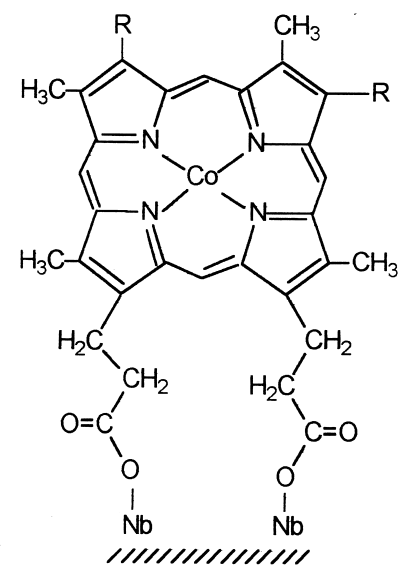

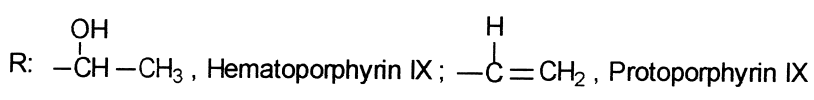

Scheme 6. Scheme of the $\mathrm{Co}(\mathrm{II})$ metallated porphyrins immobilized on $\mathrm{SiO}_{2} / \mathrm{Nb}_{2} \mathrm{O}_{5}$.

\subsubsection{Hydrazine and cysteine sensor}

The catalytic properties of metallophthalocyanines immobilized on $\mathrm{SiO}_{2} / \mathrm{TiO}_{2}$ have been explored as sensors for the indicated chemical species ${ }^{78-80}$. Iron tetra-sulfophthalocyanine immobilized on $\mathrm{SiO}_{2} / \mathrm{TiO}_{2}$ shows great stability in acid ${ }^{78}$. In a similar way, nickel tetra-sulfophthalocyanine immobilized on $\mathrm{SiO}_{2} / \mathrm{TiO}_{2}$ was used for development of an electrochemical sensor for hydrazine ${ }^{79}$.

\subsubsection{NADH sensor}

Meldola's blue (MB) immobilized on a $\mathrm{SiO}_{2} / \mathrm{TiO}_{2} /$ Phosphate carbon paste electrode ${ }^{45}$ is an effective electron mediator for NADH.

Methylene blue was immobilized on a $\mathrm{SiO}_{2} / \mathrm{Nb}_{2} \mathrm{O}_{5}$ surface and a carbon paste electrode of this material was also tested to oxidize $\mathrm{NADH}^{81}$. An important characteristic of the electrode is that the redox potential was not affected between $\mathrm{pH} 4$ and 7 .

\subsubsection{Fructose biosensor}

A carbon paste electrode made with $\mathrm{SiO}_{2} / \mathrm{TiO}_{2} /$ Phosphate/MB was used as a biosensor for fructose ${ }^{46}$ and salicylate $^{47}$. In both cases, the presence of the mediator allowed the application of a low overpotential for the detection of the analytes. The electrode was prepared by incorporating fructose 5-dehydrogenase (FDH). The enzyme FDH catalyses the oxidation of D-fructose to 5keto-D-fructose ${ }^{82}$ :

D-fructose + aceptor(ox) $\stackrel{\text { FDH }}{\longrightarrow}$

5-keto-D-fructose + aceptor(red)

This biosensor was used to determine fructose in sweets and fruit jellies.

\subsubsection{Salicylate biosensor}

In the case of the biosensor for salicylate ${ }^{47}$, the reaction catalysed by the enzyme salicylate hydroxylase can be represented by the equation:

Salicylate $+\mathrm{NADH}+\mathrm{O}_{2} \stackrel{\text { salicylate hydroxylase }}{\longrightarrow}$ catechol $+\mathrm{NAD}^{+}+\mathrm{CO}_{2}$

The consumption of NADH or $\mathrm{O}_{2}$ or the formation of catechol or $\mathrm{CO}_{2}$ can be measured and are proportional to the salicylate concentration. This biosensor detects the cathecol produced in the enzymatic reaction through its electroxidation on the mediator.

\subsubsection{Glucose biosensor}

The immobilization of ferrocene carboxylic acid and the enzyme glucose oxidase on the surface of $\mathrm{SiO}_{2} / \mathrm{TiO}_{2}$ was reported ${ }^{83}$. The electrode is used to determine glucose in blood serum ${ }^{83}$. The mechanism of the electron transfer was proposed as being electron tunnelling by the flavin of the enzyme to the mediator, and the high current level was assigned to the high surface area of the silica matrix. The immobilized material presented excellent stability, maintaining the same activity for at least six months. 


\subsubsection{Phenol biosensor}

Recently, Kubota et al. ${ }^{84}$ immobilized horseradish peroxidase on $\mathrm{SiO}_{2} / \mathrm{TiO}_{2}$ and used this for biosensor development. The direct electron transfer of hydrogen peroxide reduction by HRP was blocked by immobilizing the enzyme on silica-titanium. In this case, the sensitivity of the biosensor improved significantly, obtaining a device with better characteristics with respect to sensitivity and operational range. The mechanism of electrode response mediated for phenol can be visualized in Scheme 7.

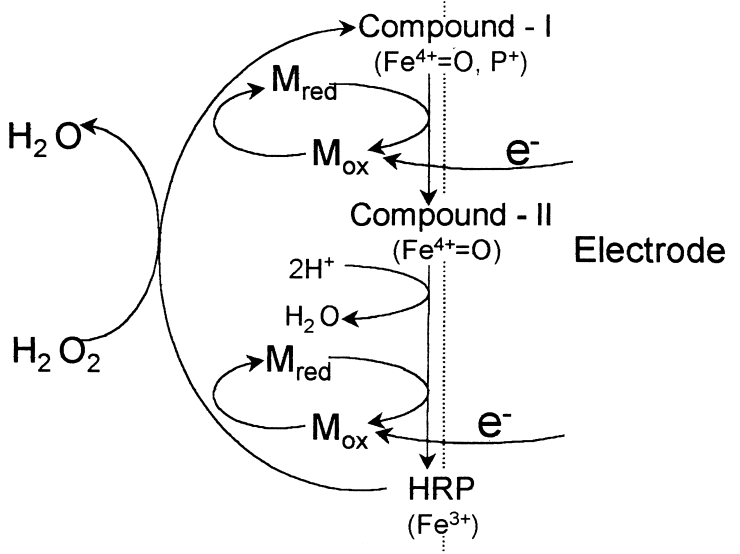

Scheme 7. Mechanism of mediated electron transfer at $\mathrm{SiO}_{2} / \mathrm{TiO}_{2} / \mathrm{HRP}-$ modified carbon paste electrode. $\mathrm{M}_{\mathrm{ox}}$ and $\mathrm{M}_{\text {red }}$ are the oxidized and reduced forms of the mediator, respectively. (Reproduction from Ref. 84 by permission of Elsevier Science B.V.).

The stability of this electrode configuration was lower, compared to that obtained for the peroxidase immobilized directly onto graphite, probably due to its environment. The influence of different additives, like bovine serum albumin (BSA), polyethylenimine (PEI) and DNA, on the sensitivity and operational stability of a phenol biosensor based on peroxidase immobilized on silica-titanium and mixed in carbon was studied ${ }^{85}$. The high sensitivity of the biosensor and the stability obtained by DNA incorporation permitted phenol determination in real samples of industrial effluents and the waters of polluted rivers. The results showed that the biosensor is more sensitive for phenol determination in the different types of samples, in comparison to the spectrometric method.

\subsubsection{Affinity biosensor}

$\mathrm{SiO}_{2} / \mathrm{TiO}_{2}$ was also used as a base for the immobilization of a single-stranded oligonucleotide ${ }^{86}$. Such immobilization proceeds through the reaction of the titanium oxide monolayer (on the silica surface) with the phosphate backbone of the oligonucleotide probe, leaving the nucleobases readily accessible for the hybridisation event.
The use of $\mathrm{SiO}_{2} / \mathrm{TiO}_{2}$ results in a homogeneous dispersion of the nucleic acid probe within the interior of the carbon paste composite. The hybridisation response obtained with this format of a DNA biosensor was reproducible.

\section{Conclusions}

Metal oxides highly and uniformly dispersed as thin monolayer surfaces on a silica gel surface constitute a class of new materials which provide a relatively inert support possessing high chemical and thermal stabilities. Despite its insulating nature, they can be successfully be used in fabrication of electrochemical devices such as electrochemical sensors. The high sensitivity achieved by using such kinds of materials is mainly due to the porous character of the $\mathrm{SiO}_{2}$ matrix used to prepare most of the materials described in this work. A very important aspect is that the matrix is rigid and does not swell when immersed in a liquid phase. From a thermodynamic point of view, such behaviour is sometimes desirable, because interface phenomena are more predictable and thus easier to study and more clearly understandable.

Recent reports have shown the potential use of these materials, especially in the construction of a class of highly sensitive electrochemical sensors ${ }^{56}$. Other possibilities are: in enzyme immobilizations, for use in water desalinisation processes, for using these materials as adsorbents of chemical species in non-aqueous solvents, for specific chemical reactions of the immobilized species and as very promising materials for use in HPLC.

\section{Acknowledgments}

The authors thank FAPESP for financial support and Professor Carol Collins for the English revision of the manuscript.

\section{References}

1. Ellestad, O. H.; Blindheim, U. J. Mol. Catal. 1985, 33, 275.

2. Ko, E. I.; Bafrali, R.; Nuhfer, N. T.; Wagner, N. J. J. Catal., 1985, 95, 260.

3. Nishimura, M.; Asakura, K.; Iwasawa, Y. J. Chem. Soc., Chem. Commun. 1986, 1660.

4. Asakura, K.; Iwasawa, Y. Chem. Lett., 1986, 859.

5. Nishimura, M.; Asakura, K.; Iwasawa, Y. Chem. Lett., 1986, 1457.

6. Bond, G. C.; Flamerz, S.; Shukri, S. Faraday Discuss. Chem. Soc. 1989, 87, 65.

7. Getty, E. E.; Drago, R. S. Inorg. Chem. 1990, 29, 1186. 
8. Shirai, M.; Ichikuni, N.; Iwasawa, Y. Catal. Today 1990, 8, 57.

9. Ichikuni, N.; Asakura, K.; Iwasawa, Y. J. Chem. Soc. Chem. Commun., 1991, 112.

10. Asakura, K.; Iwasawa, Y. J. Phys. Chem. 1991, 95, 1711.

11. Shirai, M.; Asakura K.; Iwasawa, Y. J. Phys. Chem. 1991, 95, 9999.

12. Kubota, L. T.; Gushikem, Y.; de Castro S. C.; Moreira, J. C. Colloids Surf. 1991, 57, 11.

13. Drago, R. S.; Petrosius S. C.; Chronister, C. W. Inorg. Chem. 1994, 33, 367.

14. Inoue, Y.; Yamazaki, H.; Kimura, Y. Bull. Chem. Soc. Jpn 1985, 116, 281.

15. Slotfeldt-Ellingsen, D.; Dahl, I.M.; Ellestad, O.H. J. Mol. Catal. 1980, 9, 423.

16. Riis, T.; Dahl, I. M.; Ellestad, O. H. J. Mol. Catal. 1983, 18, 203.

17. Baltes, M.; Collart, O.; Van Der Voort, P.; Vansant, E. F. Langmuir 1999, 15, 5841.

18. Wachs, I. E.; Deo, G.; Vuurman, M. A.; Hu, H.; Kim, D. S.; Jehng, J. J. Mol. Catal. 1993, 82, 443.

19. Collart, O.; Van Der Voort, P.; Vansant, E. F.; Gustin, E.; Bowen, A.; Schoemaker, D.; Rao, R. R.; Weckhuysen, B. M.; Schoonheydt, R. A. Phys. Chem. Chem. Phys. 1999, 1, 4099.

20. Meijers, A. C. Q. M.; de Jong, A. M.; Van Gruijthuijsen, L. M. P.; Niemantsverdriet, J. W. Appl. Catal. 1991, $70,53$.

21. Damyanova, S.; Grange, P.; Delmon, B. J. Catal. 1997, 168, 421.

22. Gao, X.; Fierro, J. L. G.; Wachs, I. E. Langmuir 1999, 15, 3169.

23. Sohn, J. R.; Jang, H. J. J. Mol. Catal. 1991, 64, 349.

24. Drago, R. S.; Getty, E. E. J. Am. Chem. Soc. 1988, $110,3311$.

25. Fisher, I. A.; Woo, H. C.; Bell, A. T. Catal. Lett. 1997, 44,11

26. Naito, S.; Tanimoto, M. J. Catal. 1995, 154, 306.

27. Denofre, S.; Gushikem, Y.; de Castro S. C.; Kawano, Y. J. Chem. Soc. Faraday Trans. 1993, 89, 1057.

28. Weissman, J. G.; Ko, E. I.; Wynblatt, P. J. Catal. 1987, $108,383$.

29. Birchall, T.; Connor, J. A.; Hillier, I. H. J. Chem. Soc. Dalton Trans. 1 1975, 71, 2003.

30. Garbassi, F. Surf. Interface Anal. 1980, 2, 165.

31. Fontaine, R.; Caillat, R.; Feve, L.; Guittet, M. J. J. Electron Spectrosc. 1977, 10, 349.

32. Wagner, C. D. (Ed.), Handbook of X-Ray Photoelectron Spectroscopy, Perkin-Elmer, Eden Prairie, MN, 1979.

33. Ikeya, T.; Senna, M. J. Non-Cryst. Solid 1988, 105, 243.
34. Prado, L. L. L.; Nascente, P. A. P.; de Castro, S. C.; Gushikem, Y. J. Mater. Sci. 2000, 35, 449.

35. Peixoto, C. R. M.; Kubota L. T.; Gushikem, Y. Anal. Proc. 1995, 32, 503.

36. Benvenutti, E. V.; Gushikem, Y; Davanzo, C. U.; de Castro, S. C.; Torriani, I. L. J. Chem. Soc. Faraday Trans. 1992, 88, 3193.

37. Zaldivar, G. A. P.; Gushikem, Y. J. Electroanal. Chem. 1992, 337, 165.

38. Benvenutti, E. V.; Gushikem, Y.; Davanzo, C. U. Appl. Spectrosc. 1992, 46, 1474.

39. Goodenough, J. B.; Manoharan, R.; Paranthaman, M. J. Am.Chem. Soc. 1990, 112, 2076.

40. Parks G. A. Chem. Reviews 1965, 65, 177.

41. Kita, H.; Henmi, N.; Shimazu, K.; Hattori, H.; Tanabe, K. J. Chem. Soc. Faraday Trans. 1981, 77, 2451.

42. Shriver, D. F. J. Am. Chem. Soc. 1963, 85, 1405.

43. Kubota, L. T.; Gushikem, Y. Electrochim. Acta 1992 , 37, 2477.

44. Andreotti, E. I. S.; Gushikem, Y; Kubota, L. T. J. Braz. Chem. Soc. 1992, 3, 21.

45. Kubota, L. T.; Gouvêa, F.; Andrade, A. N.; Milagres, B. G.; Oliveira Neto, G. Electrochim. Acta 1996, 411465.

46. Garcia, C. A. B.; Oliveira Neto, G.; Kubota, L. T.; Grandin, L. A. J. Electroanal. Chem. 1996, 418, 147.

47. Kubota, L. T.; Milagres, B. G.; Gouvea, F.; Oliveira Neto, G. Anal. Lett. 1996, 29, 893.

48. Rocha, R. F.; Rosatto, S. S.; Bruns, R. E.; Kubota, L. T. J. Electroanal. Chem. 1997, 433, 73.

49. Peixoto, C. R. M.; Kubota, L. T.; Gushikem, Y. J. Braz. Chem Soc. 1995, 6, 83.

50. Zaldivar, G. A. P.; Gushikem, Y.; Kubota, L. T. J. Electroanal. Chem. 1991, 318, 247.

51. Kubota, L. T.; Gushikem, Y. J. Electroanal. Chem. 1993, 362, 219.

52. Zaldivar, G.A.P.; Gushikem,Y.; Benvenutti,E. V.; de Castro, S. C.; Vasquez, A. Electrochim. Acta 1994, 39, 33.

53. da Cunha, L. J.V.; Andreotti, E. I.S.; Gushikem, Y. J. Braz. Chem. Soc. 1995, 6, 271.

54. Moelwyn-Hughes, E. A. Physical Chemistry, Pergamon Press, London, 1961, p 587.

55. Seifer, G. S. B. Russ. J. Inorg. Chem.,1962, 7, 621.

56. Gushikem, Y.; Peixoto, C. R. M.; Rodrigues Filho, U. P.; Kubota, L. T.; Stadler, E. J. Colloid Interface Sci. 1996, 184, 236.

57. Denofre, S.; Gushikem, Y.; Davanzo, C. U. Eur. J. Solid State Inorg. Chem. 1991, 28, 1295.

58. Pessôa, C. A.; Gushikem, Y. J. Electroanal. Chem. 1999, 477, 158.

59. Pessôa, C. A.; Gushikem, Y.; Kubota, L. T. Electrochim. Acta 2001, 46, 2499. 
60. Kubota, L. T.; Gushikem, Y.; Mansanares, A. M.; Vargas, H. J. Colloid Interface Sci. 1995, 173, 372.

61. Benvenutti, E. V.; Gushikem, Y.; Vasquez, A.; de Castro S. C.; Zaldivar, G. A. P. J. Chem. Soc., Chem. Commun. 1991, 1325.

62. Davanzo, C. U.; Gushikem, Y.; de Castro, S. C.; Benvenutti, E. V.; Vasquez, A. J. Chem. Soc., Faraday Trans. 1996, 92, 1569.

63. Benvenutti, E. V.; Gushikem, Y. J. Braz. Chem. Soc. 1998, 9, 469.

64. Kubota, L. T.; Gushikem, Y.; Moreira, J. C. Analyst 1991, 116, 281.

65. Gushikem, Y.; Peixoto, C. R. M.; Kubota, L. T. In New Developments in Ion Exchange. Materials, Fundamentals and Applications, Proceedings of the International Conference on Ion Exchange, ICIE'91, Tokyo, Jpn, 1991, 607.

66. Peixoto, C. R. M.; Gushikem Y.; Baccan, N. Analyst 1992, 117, 1029.

67. Nagata, N.; Kubota, L. T.; Bueno M. I. M. S.; PeraltaZamora, P. G. J. Colloid Interface Sci. 1998, 200, 121.

68. Nagata, N.; Peralta-Zamora, P. G.; Kubota, L. T.; Bueno, M. I. M. S. Anal. Sci. 1999, 15, 761.

69. Nagata, N.; Peralta-Zamora, P. G.; Kubota L. T.; Bueno, M. I. S. Anal. Lett. 2000, 33, 2005.

70. Gushikem, Y.; Alfaya R. V. S.; Alfaya, A. A. S. Brazilian Patent, BR9803053-A 1998.

71. Fujiwara, S. T.; Gushikem Y.; Alfaya, R. V. S. Colloids Surf., A 2001, 178, 135.
72. Silva R. B.; Collins, C. H. J. Chromatogr., A $\mathbf{1 9 9 9 ,}$ $845,417$.

73. Melo L. F. C.; Jardim, I. C. S. F. J. Chromatogr., A 1999, 845, 423.

74. Silva, R. B.; Collins K. E.; Collins, C. H. J. Chromatogr., A 2000, 869, 137.

75. Melo, L. F. C.; Collins, C. H.; Collins K. E.; Jardim, I. C. S. F. J. Chromatogr., A 2000, 869, 129.

76. Silva, R. B.; Gushikem Y.; Collins, C. H. J. Sep. Sci. 2001, 24, 1.

77. Walcarius, A. Electroanalysis 1998, 10, 1217.

78. Kubota, L. T.; Gushikem, Y.; Perez, J.; Tanaka, A. A. Langmuir 1995, 11, 1009.

79. Perez, E. F.; Kubota, L. T.; Tanaka, A. A.; Oliveira Neto, G. Electrochim. Acta 1998, 43, 1665.

80. Perez, E. F.; Oliveira Neto, G.; Tanaka, A. A.; Kubota, L. T. Electroanalysis 1998, 10, 111.

81. Schiavo, D. A.; Perez, E. F.; Kubota, L. T. Quim. Nova 2000, 23, 832.

82. Yamada, Y.; Ainda K.; Uemura, I. Agric. Biol. Chem. 1966, 30, 95.

83. Milagres, B. G.; Kubota, L. T.; Oliveira Neto, G. Electroanalysis 1996, 8, 489.

84. Rosatto, S. S.; Kubota, L. T.; Oliveira Neto, G. Anal. Chim. Acta 1999, 390, 65.

85. Rosatto, S. S.; Kubota, L. T.; Oliveira Neto, G. Electroanalysis 2001, 13, 445.

86. Wang, J.; Fernandes, J. R.; Kubota, L. T. Anal. Chem. 1998, 70, 3699.

Received: May 4, 2001

Published on the web: September 13, 2001

FAPESP helped in meeting the publication costs of this article. 